\title{
Experiences with dormancy in tardigrades
}

\author{
Roberto BERTOLANI*, Roberto GUIDETTI, K. Ingemar JÖNSSON ${ }^{1)}$, Tiziana ALTIERO, Deborah BOSCHINI and \\ Lorena REBECCHI
}

Department of Animal Biology, University of Modena and Reggio Emilia, via Campi, 213/D - 41100 Modena, Italy

${ }^{1)}$ Department of Theoretical Ecology, Lund University, Ecology Building, S-223 62 Lund, Sweden

*e-mail corresponding author: bertolani.roberto@unimore.it

\begin{abstract}
Tardigrades often colonise extreme habitats, in which they survive using both types of dormancy: quiescence and diapause. Together with nematodes and bdelloid rotifers, tardigrades are known to enter quiescence (with several forms of cryptobiosis: anhydrobiosis, cryobiosis, anoxybiosis, osmobiosis) at any stage of their life cycle, from egg to adult. Entering anhydrobiosis, tardigrades contract their body into a so-called tun, loosing most of their free and bound water (>95\%), synthesizing cell protectants (e.g., trehalose, glycerol, heat shock proteins) and strongly reducing or suspending their metabolism. Our research on cryptobiosis focused on some ecological and evolutionary aspects. We evaluated: i) the long-term anhydrobiotic survival by comparing quantitative data on recovery from naturally induced desiccation in several species of tardigrades; ii) differences in survival patterns between species and populations by experimentally inducing anhydrobiosis and cryobiosis; iii) phenotypic factors affecting anhydrobiotic survival. As regards diapause, we considered encystment and eggs. Encystment involves at least the synthesis of new cuticular structures. Morphological changes during cyst formation are more complex than those involved in tun formation. We analyzed more in detail encystment processes, comparing a semiterrestrial with a limnic species. Several inter-specific differences have been identified, other than the production of two types of cysts in the semiterrestrial species. Our analysis of life history traits of a laboratory reared strain of a soil tardigrade revealed a particular hatching phenology that involved the production of both subitaneous and resting eggs. The latter need a cue to hatch (dehydration followed by re-hydration). In addition, the evolutionary meaning of dormancy in tardigrades is discussed.
\end{abstract}

Key words: anhydrobiosis, cryobiosis, encystment, resting eggs, Tardigrada, dormancy evolution

\section{INTRODUCTION}

Tardigrades are metameric invertebrates found worldwide in a variety of habitats within marine, freshwater and terrestrial ecosystems. The species inhabiting terrestrial habitats are active only when surrounded by at least a film of water. When deprived of their free water, they survive using their well-known capability to enter cryptobiosis. This capability also allows tardigrades to colonise extreme environments such as deserts, high mountains and polar regions. Together with nematodes and bdelloid rotifers, tardigrades are known to enter cryptobiosis at any stage of their life cycle, from egg to adult. Cryptobiosis has to be considered a form of quiescence, being directly induced and maintained by the occurrence of adverse conditions for an active life, and promptly broken once the adverse conditions are removed (e.g., Keilin 1959; Hand 1991). In tardigrades, there are several forms of cryptobiosis: anhydrobiosis, cryobiosis, anoxybiosis and osmobiosis. Anhydrobiosis is the most studied. Entering anhydrobiosis, tardigrades contract their body into a so-called tun, loosing most of their free and bound water $(>95 \%)$, synthesizing cell protectants (e.g., trehalose, glycerol, heat shock proteins; Westh \& Ramløv 1991; Ramløv \& Westh 2001) and strongly reducing or suspending their metabolism (Clegg 2001; Wright 2001). Cryptobiosis is associated with a resistance to temperatures near absolute zero (Becquerel 1950) and well above $100{ }^{\circ} \mathrm{C}$ (Doyère 1842; Rahm 1921), very high levels of ionising radiation (May et al. 1964) and hydrostatic pressure (Seki \& Toyoshima 1998). References on long-term anhydrobiotic survival in tardigrades are scarce and sometimes not sufficiently supported by empirical data. In particular, a reference on cryptobiotic survival of more than one century has to be rejected (Jönsson \& Bertolani 2001). Tardigrades overcome adverse conditions also by forming cysts, i.e., by reducing their metabolism even less than in the anhydrobiosis state (Pigòn \& Węglarska 1953), without loosing large quantities of water. This capability characterises several limnic tardigrades, but sometimes also some soil and moss-dwelling tardigrades. True limnic tardigrades carry out only encystment, whereas some soil- or moss-dwelling species have the capability to use both anhydrobiosis and encystment. Encystment has to be considered a form of diapause, dormancy under endogenous control induced by external stimuli (i.e., reduced temperature, drought, changed photoperiod) or by individual genotype (programmed diapause), which, in contrast to quiescence, does not automatically arrest with the termination of adverse conditions (Hickman Jr. et al. 1993). Tardigrade cysts have a contracted and oval distinctive form, and evident thick and dark cuticular layers (Ramazzotti 1962). The 
phenology, physiology and ecological causes of cyst formation are poorly known and the available data are often contradictory. Literature data report that cyst formation requires, other than body contraction, morphological modifications of internal organs and synthesis of new cuticular structures (Węglarska 1957; Westh \& Kristensen 1992; Hansen \& Katholm 2002).

Eggs of tardigrades can survive in a dehydrated state just as the animals (the most recent data are reported by Guidetti \& Jönsson 2002) but other forms of egg dormancy in tardigrades are practically unknown. According to some authors, thick-shelled eggs are produced when environmental conditions are unfavourable (Pennak 1953; Kinchin 1994). Firm evidence of resting eggs in tardigrades has never been demonstrated. There are however two citations of a population of the eutardigrade Amphibolus nebulosus from Greenland, which ife cycle involves two types of cysts and two types of eggs called "winter egg" and "summer egg" (Westh \& Kristensen 1992; Hansen \& Katholm 2002).

The present paper refers to our research on dormancy in tardigrades. Its focuses on micro- and macroevolutionary patterns of dormancy, a field where little is known for this group of micrometazoans. We considered both cryptobiosis and encystment and also evaluated other possibilities of dormancy.

\section{CRYPTOBIOSIS}

With regards to cryptobiosis, we evaluated: i) the long-term anhydrobiotic survival, comparing quantitative data on recovery from naturally induced desiccation in several species of tardigrades; ii) differences in survival patterns between species and populations, experimentally inducing anhydrobiosis and cryobiosis; iii) phenotypic factors affecting anhydrobiotic survival.

\subsection{Long-term anhydrobiotic survival}

In order to obtain a better understanding of the capability of tardigrades to recover from long-term anhydrobiosis after storage under atmospheric oxygen conditions, we evaluated: i) the longevity of naturally dried lichen-dwelling tardigrades using a statistical approach (Rebecchi et al., in press); ii) the presence of survivors in a large number of old moss and lichen samples stored dry from 9 to 138 years, obtained from botanical museums and private collectors (Guidetti \& Jönsson 2002).

The evaluation of the longevity of naturally dried lichen-dwelling tardigrades was carried out by examining a lichen (Xanthoria parietina) collected dry near Modena (Italy) two days after a rainy day in April 1999. The dry lichen was stored in a paper bag and maintained dry in the laboratory at room temperature and humidity and with exposure to atmospheric oxygen, with humidity and temperature constantly recorded (Rebecchi et al., in press). Tardigrade survival was verified during 20 checks at prefixed dates during a period of 1604 days (about 4 years and 5 months). At each check, eight different sub-samples were analysed. As a criterion for animal viability, coordinated movements of the body were considered. Five species of tardigrades were found in the samples. Milnesium tardigradum and Macrobiotus richtersi were only occasionally found, while Ramazzottius oberhaeuseri (Eutardigrada; Figs 1A and 1B), Echiniscus testudo and Echiniscus trisetosus (Figs 1C, 1D and 1E) (Heterotardigrada) were sufficiently represented for statistical analyses.

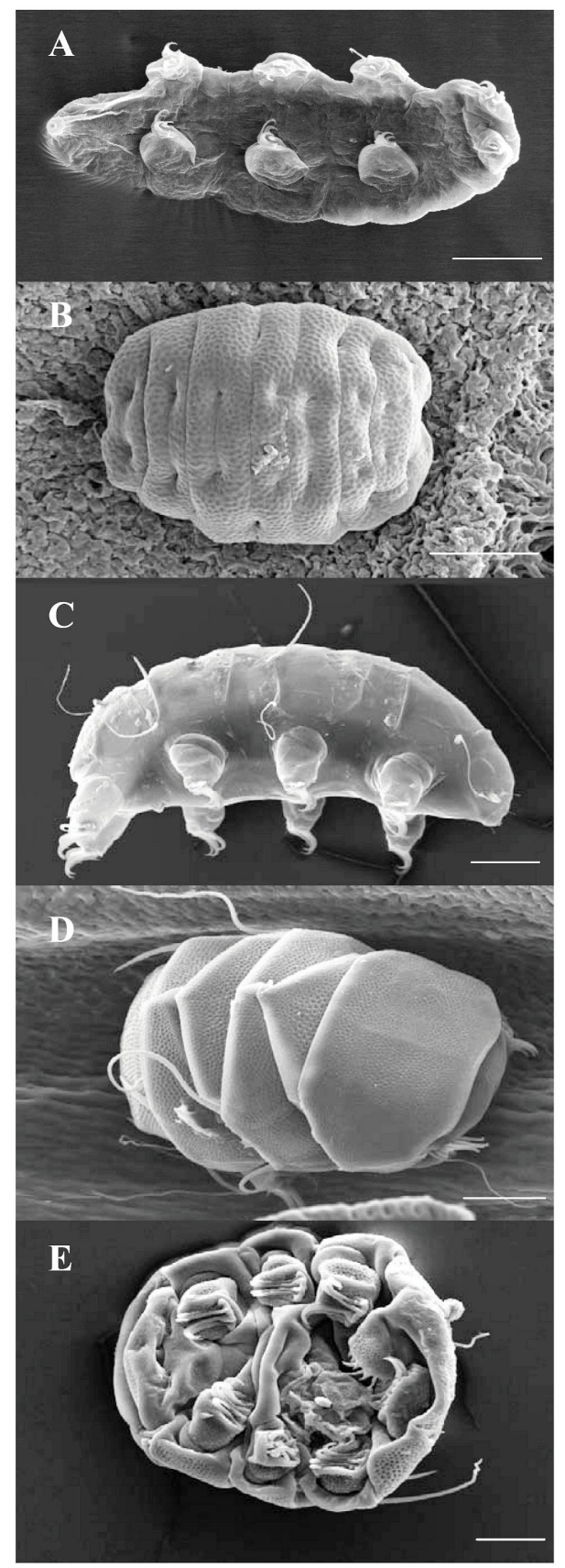

Fig. 1. Scanning electron micrographs of active and anhydrobiotic tardigrades. A-B: Active specimen (A) and dorsal view of a tun (B) of the eutardigrade Ramazzottius oberhaeuseri. CE: Lateral view of active specimen (C) and tuns in dorsal (D) and ventral (E) view of the heterotardigrade Echiniscus trisetosus. Scale bar $=50 \mu \mathrm{m}$. 

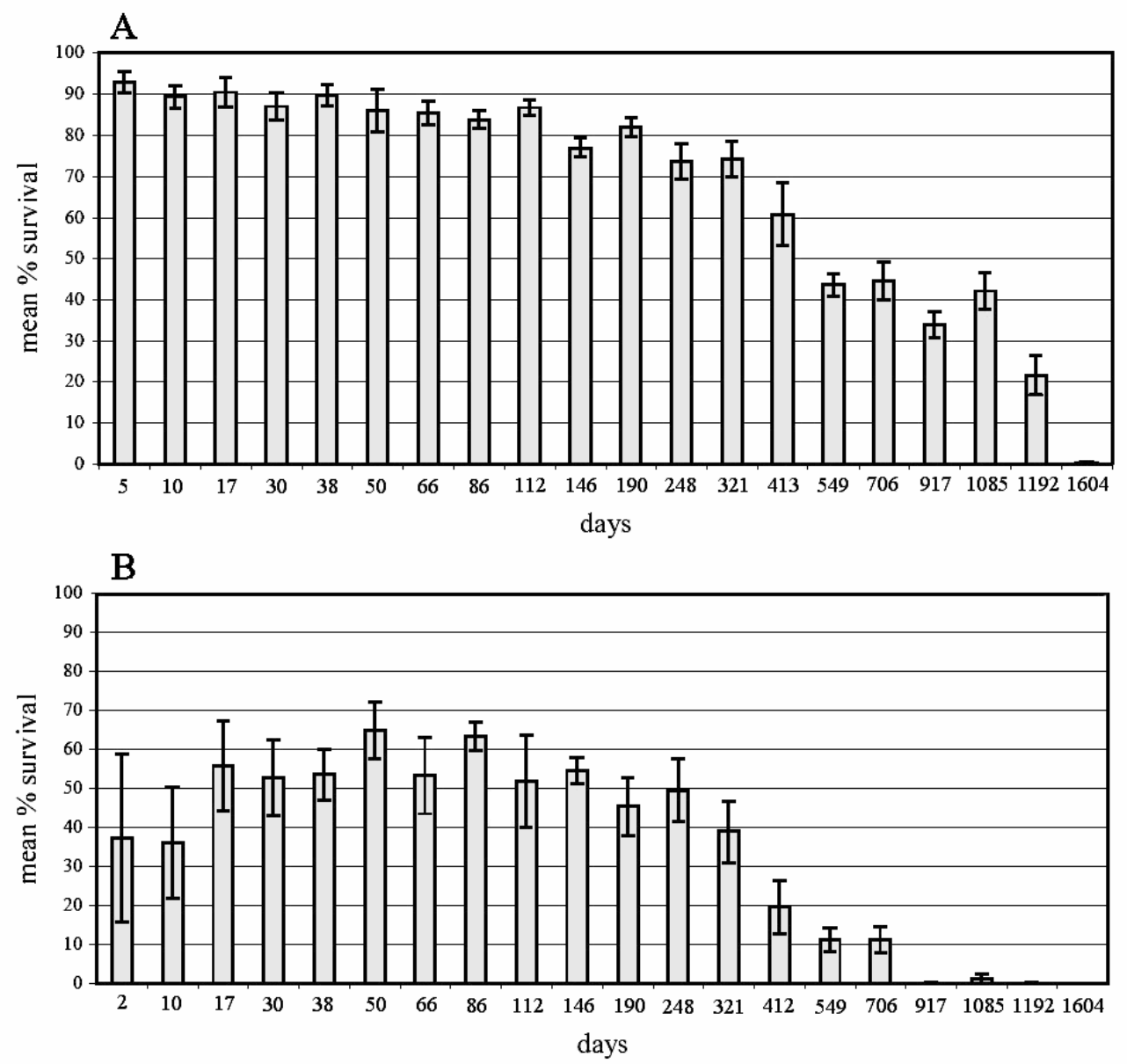

Fig. 2. Dynamics of long-term anhydrobiotic survival. A: Ramazzottius oberhaeuseri. B: Echiniscus spp. Each column represents the mean percentage (of the 8 sub-samples) of alive specimens in each check. Standard error is also represented. (From Rebecchi et al. 2004).

At the beginning of the experiment the survival rate was $91.1 \%$ for $R$. oberhaeuseri (Fig. 2A) and $71.7 \%$ for Echiniscus spp. Specimens of Ramazzottius oberhaeuseri survived up to 1604 days from the beginning of the experiments (last check carried out), while specimens of Echiniscus spp. lived up to 1085 days (Fig. 2B). The first significant decrease in recovery of $R$. oberhaeuseri was observed after 86 days from the beginning of the experiment; at this time the percentage of live specimens was $85.1 \%$. In addition, in $R$. oberhaeuseri recovery time to reach active life increased with time spent in anhydrobiosis. The first significant decrease in the recovery of Echiniscus spp. was observed after 412 days from the beginning of the experiment. At this check the percentage of live specimens was $16.8 \%$. Statistical comparison between the survival rate of $R$. oberhaeuseri and that of Echiniscus spp. showed that the survival of $R$. oberhaeuseri was significantly higher than that of Echiniscus spp. Four eggs of $R$. oberhaeuseri and eight eggs of Milnesium tardigradum, collected from lichen after 1604 days, hatched after hydration (Rebecchi et al. 2004).

The presence of survivors of tardigrades (as well as nematodes and rotifers) in sixty-three different samples of moss and lichen from public and private collections, kept dry for 9-138 years, has been considered (Guidetti \& Jönsson 2002). No live juvenile or adult tardigrades were found, while some rotifers of the genus Mniobia were recovered from a moss sample 9 years old. Nevertheless, 4 eggs of $R$. oberhaeuseri hatched from a total of 13 collected from a 9 year old lichen.

\subsection{Inter-and intraspecific differences in survival patterns}

\subsubsection{Anhydrobiosis}

A study was carried out on anhydrobiotic survival in two geographically isolated populations of two species of eutardigrades, to fill the gap of knowledge on interand intraspecific variations in cryptobiotic capacity in tardigrades (Jönsson et al. 2001). One population from Sweden and another from Italy were considered for both Richtersius coronifer and Ramazzottius oberhaeuseri. Using the same experimental conditions, specimens were experimentally dehydrated and maintained for 12 days in anhydrobiosis, then re-hydrated and evaluated for survival (Jönsson et al. 2001). Anhydrobiotic survival was similar in the Swedish and the Italian popula- 
tions in both species (Fig. 3), indicating no or very little divergence with respect to anhydrobiotic capacity. The overall survival of $R$. oberhaeuseri was $66 \%$, while only $40 \%$ of $R$. coronifer specimens survived.

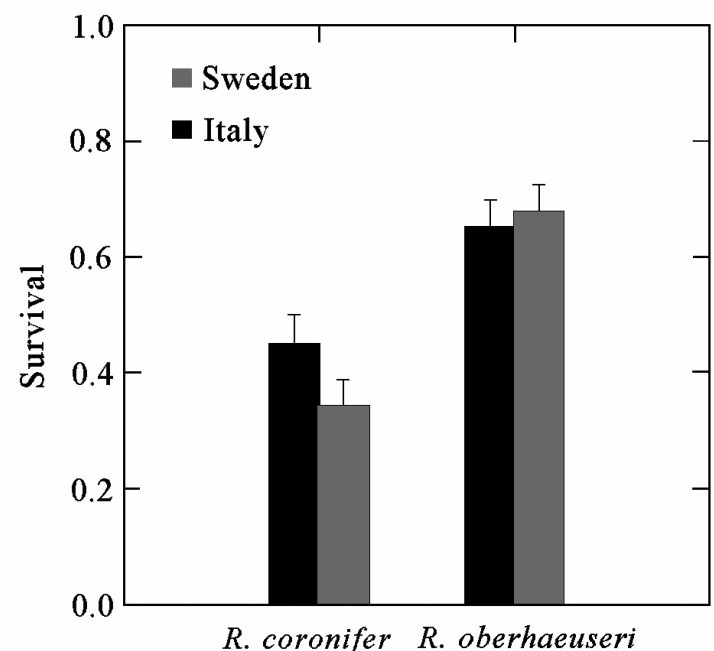

Fig. 3. Anhydrobiotic survival in populations of Richtersius coronifer and Ramazzottius oberhaeuseri from Italy and Sweden. Standard error is also represented. (From Jönsson et al. 2001).

\subsubsection{Cryobiosis}

Cryobiotic survival has also been considered (Guidetti et al., unpublished data). Four species of eutardigrades belonging to two families and living on different substrates have been analysed. Two species belong to Hypsibiidae: Ramazzottius oberhaeuseri (lichendwelling) and Hypsibius dujardini (freshwater-dwelling, reared in lab); the other two species belong to Macrobiotidae: Dactylobiotus parthenogeneticus (freshwaterdwelling) and Macrobiotus richtersi (leaf litter-dwelling). Active animals were put in $4 \mathrm{ml}$ of distilled water and kept 2-3 hours at $14{ }^{\circ} \mathrm{C}$ before freezing. Subsequently, the animals were subdivided into groups, and frozen at different temperatures $\left(-9{ }^{\circ} \mathrm{C},-20^{\circ} \mathrm{C}\right.$ and -80 $\left.{ }^{\circ} \mathrm{C}\right)$. For each temperature, eight replicates were considered, except for D. parthenogeneticus, for which only two replicates were considered. The animals were kept frozen for 6 days, put at $-9{ }^{\circ} \mathrm{C}$ overnight and then thawed gradually at $12{ }^{\circ} \mathrm{C}$. Survival was evaluated 24 hours after the beginning of thawing. ANOVA and Mann-Whitney tests were used for statistical analysis. The four species considered show different patterns of cryobiotic survival (Fig. 4). The terrestrial species $R$. oberhaeuseri and $M$. richtersi showed a high survival rate, while the freshwater species showed a limited capability (H. dujardini) or inability (D. parthenogeneticus) to perform cryobiosis under such conditions. Ramazzottius oberhaeuseri had the highest survival rate at all temperatures considered and its survival was not influenced by experimental temperature. Highly signifi- cant differences in survival $(\mathrm{p}<0.01)$ related to the different freezing temperatures were found in $M$. richtersi (between $-9{ }^{\circ} \mathrm{C}$ and $-80{ }^{\circ} \mathrm{C}$ ) and in $H$. dujardini (between $-20{ }^{\circ} \mathrm{C}$ and $-80{ }^{\circ} \mathrm{C}$, and between $-9{ }^{\circ} \mathrm{C}$ and -80 $\left.{ }^{\circ} \mathrm{C}\right)$.

\subsection{Phenotypic factors affecting anhydrobiotic survival}

A laboratory study on the effects of body size, reproductive condition (oocytes maturation stage), and energetic condition (storage cell size) on anhydrobiotic survival was carried out in a population of the eutardigrade Richtersius coronifer from Sweden (Jönsson \& Rebecchi 2002). Survival was evaluated in specimens experimentally dehydrated and maintained for 12 days in anhydrobiosis, then rehydrated. Phenotypic characteristics were measured in hydrated specimens before and after the period of anhydrobiosis. Among the three variables examined, both body size and energetic condition affected anhydrobiotic survival, while reproductive condition had no effect. Large tardigrades had a lower probability of survival than medium sized tardigrades, and showed a positive response in survival to energetic condition (Fig. 5).

\section{ENCYSTMENT}

Two species of eutardigrades from different habitats were considered and compared with respect to encystment: Amphibolus volubilis (Eohypsibiidae), mossdwelling, and able both to enter cryptobiosis and to form cysts, and Dactylobiotus parthenogeneticus (Macrobiotidae), freshwater-dwelling, and only able to form cysts. For both species, cysts were collected in nature and also induced under laboratory conditions (Guidetti et al. 2004). The cyst morphology and encystment processes were analysed by light microscopy, SEM and TEM. Amphibolus volubilis produces two types of cysts ("type 1" cyst and "type 2" cyst; Figs 6A and 6B), while D. parthenogeneticus produced only one type (Fig. 6E). The cyst is composed of a series of cuticles surrounding the animal and resembles an onion or a Matrioshka Russian doll. The number of cuticles is related to the species and/or to the types of cyst. Undescribed processes and several interspecific differences have been observed during cyst formation. In any case, encystment involves synthesis of new cuticles and of new buccal-pharyngeal apparatuses. It begins with the discharging of the sclerified parts of the buccal-pharyngeal apparatus, as in normal moulting, but without the loss of the old animal cuticle. During the encystment process, animals of both species reduce their body size by contracting longitudinally, and decrease the body movements up to a complete stand still. Two or three new cuticles are serially synthesised, according to the type of cyst. In A. volubilis, the ultrastructure of these new cuticles is similar to that of the active and non-encysted animals, while in $D$. parthenogeneticus the ultrastructures of the new cuticles differ from that of the active and non-encysted speci- 


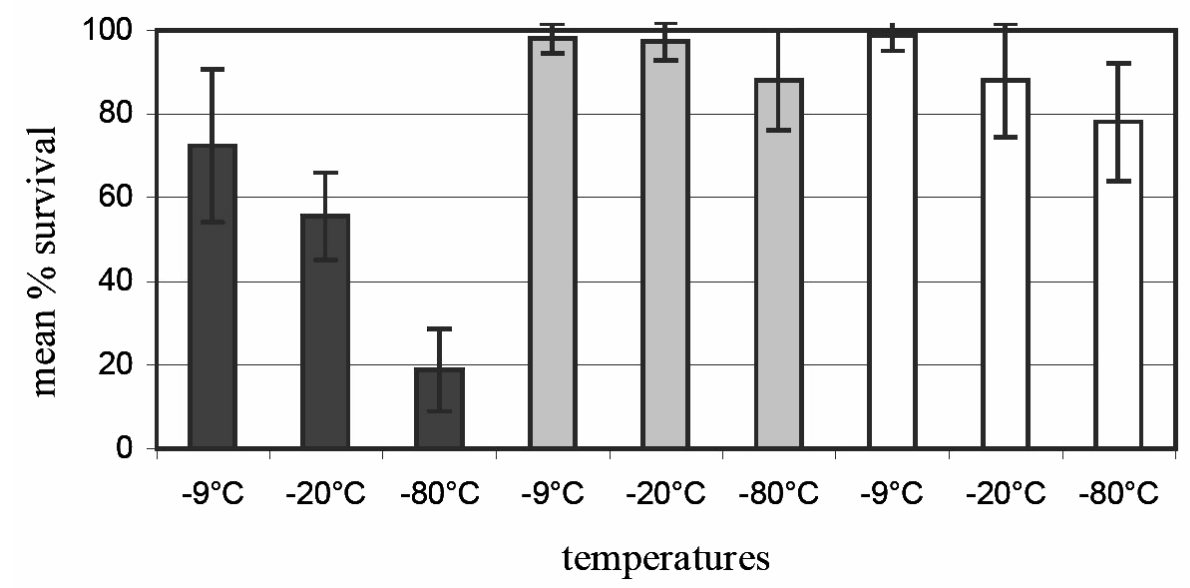

Fig. 4. Cryobiotic survival of Hypsibius dujardini, Ramazzottius oberhaeuseri and Macrobiotus richtersi frozen at three different temperatures. Each column represents the mean percentage of live specimens. Standard error is also represented. Black columns $=$ Hypsibius dujardini; grey columns = Ramazzottius oberhaeuseri; white columns = Macrobiotus richtersi .

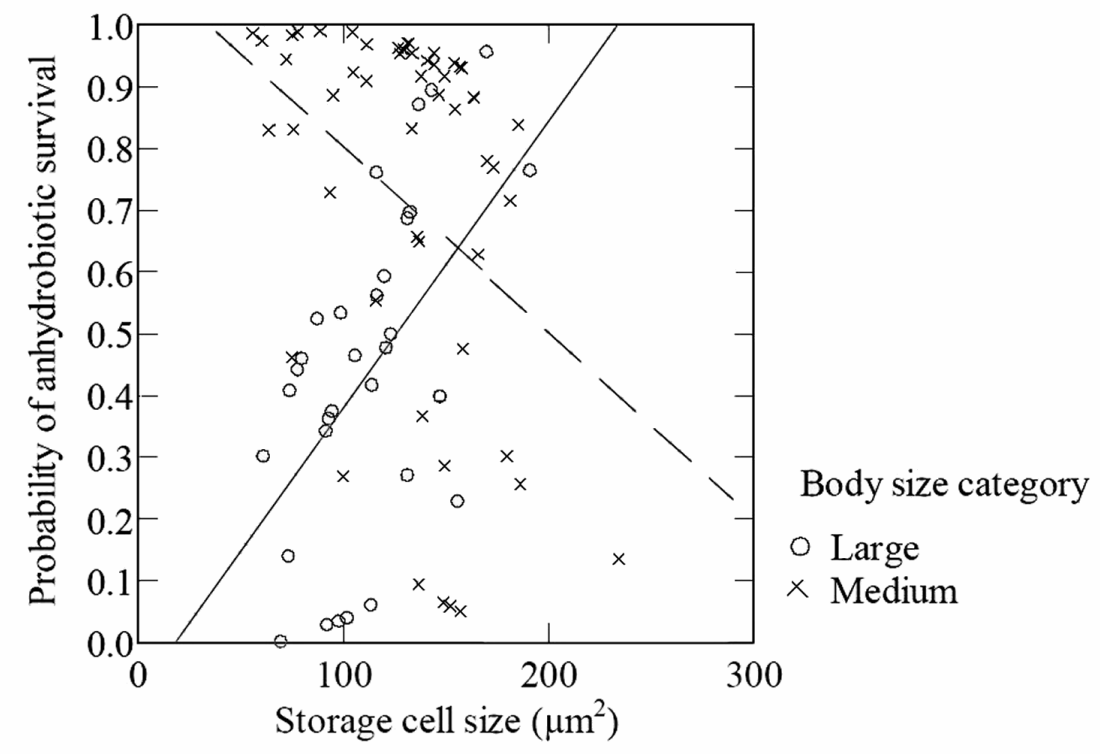

Fig. 5. Probability of anhydrobiotic survival for large (solid line) and medium (broken line) specimens of the eutardigrade Richtersius coronifer as a function of storage cell size. Probability represents the predicted values obtained from a logistic regression model, buccal tube length category, storage cell size and the interaction between the last two categories. (From Jönsson \& Rebecchi 2002).

mens. The "type 1 " cyst of $A$. volubilis has one cuticle less than the "type 2 " cyst; moreover the "type 1 " cyst never shows a modified buccal-pharyngeal apparatus. A modified buccal-pharyngeal apparatus, up to date undescribed, has been observed both in "type 2" cyst of $A$. volubilis (Figs $6 \mathrm{C}$ and $6 \mathrm{D}$ ) and in the $D$. parthenogeneticus cyst (Guidetti et al. 2004).

\section{RESTING EGGS}

Our preliminary data on a laboratory reared strain of soil tardigrade, Macrobiotus richtersi (apomictic cytotype), show a diversified hatching phenology (Altiero et al. 2004). The hatching time was extreme variable: from
16 to 111 days, with $83 \%$ hatching in one clone and $51 \%$ hatching in another. Further experiments on hatching phenology have been carried out on the same species (Rebecchi \& Altiero, unpublished data). Eggs from the first oviposition in lab of females sampled in nature in spring and in fall, and eggs of all clutches of two cohorts reared in lab were investigated. All the laid eggs were maintained in water at the same temperature, $14{ }^{\circ} \mathrm{C}$, up to the eventual hatching. About $90 \%$ of eggs hatched after 30-62 days from oviposition. The eggs remaining unhatched after 90 days were dried, maintained dry for 21 days and then rehydrated. Five of them, belonging to different ovipositions, hatched after 
rehydration, indicating that in $M$. richtersi, subitaneous and resting eggs may be present.
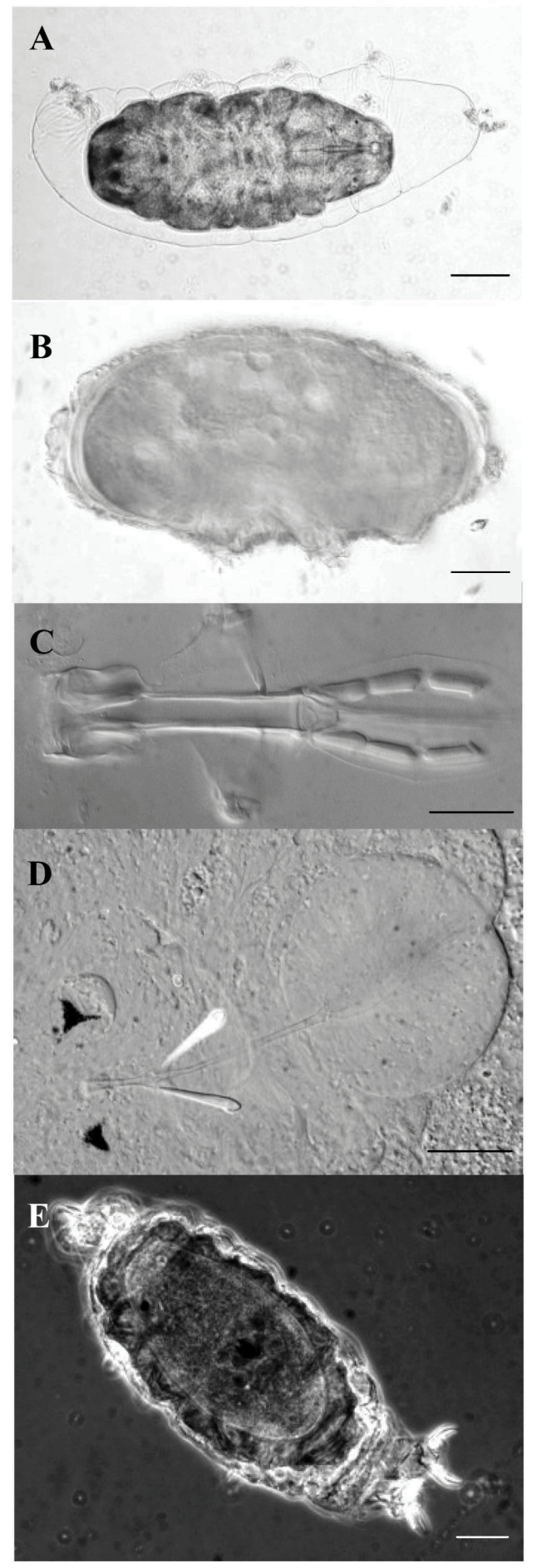

Fig. 6. A-B: Type 1 cyst (A) and type 2 cyst (B) of the mossdwelling eutardigrade Amphibolus volubilis (phase contrast); note the animals surrounded by several cuticles. C: Normal buccal-pharyngeal apparatus of an active specimen of $A$. volubilis (Nomarski contrast). D: Modified buccal-pharyngeal apparatus of type 2 cyst of $A$. volubilis (Nomarski contrast). E: Cyst of the freshwater eutardigrade Dactylobiotus parthenogeneticus (phase contrast). Scale bar: A, B $=50 \mu \mathrm{m} ; \mathrm{C}-\mathrm{E}=10 \mu \mathrm{m}$.

\section{DISCUSSION}

A recovery after four (animals) and nine (eggs) years of anhydrobiosis, as in our experiments, has to be considered a very good long-term survival, although the ecological and evolutionary importance of such capability remains unclear. The results obtained in our experiment on dehydrated tardigrades stored under atmospheric oxygen and humidity (Rebecchi et al. 2004) are similar to those obtained by Crowe (1975) for Macrobiotus areolatus. Other studies on anhydrobiotic survival of tardigrades exposed to similar conditions revealed a maximum value of 7 years (Baumann 1922). A similar long-term survival in anhydrobiosis also characterises bdelloid rotifers (Rahm 1921; Guidetti \& Jönsson 2002), which, similarly to tardigrades and nematodes, colonise terrestrial environments such as mosses and lichens. Nevertheless, among metazoans, nematodes have the highest survival in anhydrobiosis (up to 39 years; see Cooper \& Van Gundy 1971; Aroian et al. 1993). The records for long-term recovery after desiccation belong to seeds of the sacred lotus, Nelumbo nucifera (1000 years; Shen et al. 1995) and to ancient bacteria (up to 250 million years old; Vreeland 2000). Our data on hatching of Milnesium tardigradum and Ramazzottius oberhaeuseri eggs after a long period of anhydrobiosis confirm that the phenomenon can occur in any stage of the tardigrade life cycle. Moreover, the data suggest that eggs may survive better than adult tardigrades (Guidetti \& Jönsson 2002).

Several factors may be involved in long-term anhydrobiotic survival. The damaging effect of oxidation processes is accepted as one of the main causes of death during long-term storage because it can destroy the molecular organisation of cells and DNA (Clegg 1967; Crowe 1975; Örstan 1998). The relative humidity to which the animals are exposed also plays an important role for long-term survival, as recorded by Örstan (1998) in anhydrobiotic rotifers. In addition, the microenvironment may play a role providing more or less exposure of the animals to external factors (e.g., humidity and oxygen).

Our studies also allowed comparisons of the longterm survival ability of different species (Rebecchi et al. 2004). Echiniscus species had a higher mortality than $R$. oberhaeuseri at the beginning of the checks and $R$. oberhaeuseri also survived much longer than Echiniscus. The first significant decrease in survival, earlier in $R$. oberhaeuseri than in Echiniscus, may be due to the high initial mortality of Echiniscus specimens, but also to the higher standard errors in Echiniscus. The higher survival of $R$. oberhaeuseri agrees with the proposition by Wright (1989) that $R$. oberhaeuseri is more tolerant to dehydration than Echiniscus species and, in particular, Echiniscus testudo.

Evident interspecific differences in cryptobiotic survival were also found after lab induced anhydrobiosis in $R$. oberhaeuseri and $R$. coronifer (see Jönsson et al. 
2001) and after lab induced cryobiosis in two species of freshwater tardigrades and two species of semiterrestrial tardigrades (Guidetti et al., unpublished data). Ramazzottius oberhaeuseri, a xerophilic species, had a much higher survival rate than $R$. coronifer, the latter of which is more hygrophilic. Large differences among species in long-term anhydrobiotic survival also exist in nematodes (Steiner \& Albin 1946; Fielding 1951; Lee 1961; McGlohon et al. 1961; Cooper \& Van Gundy 1971; Townshend 1964; Aroian et al. 1993) and in bdelloid rotifers (Ricci 1998). As regards cryobiosis, the species known as xerophilic or with a good anhydrobiotic capacity ( $R$. oberhaeuseri, $M$. richtersi) also have high cryobiotic survival rates, in agreement with what has been hypothesised by Ramløv \& Westh (1992). On the contrary, freshwater species such as $H$. dujardini and $D$. parthenogeneticus (which in our lab did not carry out anhydrobiosis), do not survive freezing very well, if at all. Our experiments of anhydrobiosis in tardigrades did not show differences between populations of the same species from different geographic areas ( $R$. oberhaeuseri and $R$. coronifer from Italy and Sweden) (Jönsson et al. 2001). Similarly, no differences in anhydrobiotic survival between populations from Greece and United Kingdom were found in two species of nematodes (Menti et al. 1997), despite the expectation that natural drying conditions in Greece had imposed selection for higher anhydrobiotic capacity. It should be remembered however that we have used only one level of desiccation condition $(65 \% \mathrm{RH})$. Studies over a wider range of conditions may be necessary before a firm conclusion may be drawn about adaptive differentiation between tardigrade populations from different areas.

The study on phenotypic factors affecting anhydrobiotic survival in tardigrades (Jönsson \& Rebecchi 2002) indicates that the phenotypic state of the individuals has an impact on the probability to survive a single period of anhydrobiosis, and that some phenotypic categories are exposed to a higher risk of anhydrobiotic failure than others. It also suggests that energy constrained the possibility for large tardigrades to enter and to leave anhydrobiosis. These results should have important implications for our view on the evolution of life histories in anhydrobiotic tardigrades. Effects of body size on anhydrobiotic survival suggest age-specific selection, and effects of energy status indicate that energy allocation to anhydrobiotic functions is also subject to selection. A decrease in the size of storage cells over a period of anhydrobiosis was also documented, confirming that energy is consumed when the animal enters or leaves (or both) anhydrobiosis in tardigrades. Fat and glycogen catabolism in connection with desiccation has also been indicated in studies on nematodes (Madin \& Crowe 1975; Demeure et al. 1978; Womersley 1981). The expression of senescence should be considered as a possible alternative explanation for low survival in large specimens in future experiments.
In tardigrades, encystment is connected with large morphological modifications of the body. The encystment is produced by processes in part common to $D$. parthenogeneticus and $A$. volubilis, in part unique to each of them. In A. volubilis, "type 2" cysts are structurally more complex than "type 1 " cysts, with a higher number of highly sclerotized cuticular involucres and with synthesis of a modified buccal-pharyngeal apparatus. The cysts of "type 1" and "type 2" found by Hansen \& Katholm (2002) in A. nebulosus have to be considered homologous to those found in A. volubilis even though some differences exist (presence of the "sarcophagus cuticle" in the "type 1" cyst in A. volubilis and presence of legs in the "mummy cuticle" of the "type 2" cyst in A. volubilis). In contrast to Dactylobiotus dispar cysts described by Weglarska (1957), we found the presence of two modified buccal-pharyngeal apparatuses in $D$. parthenogeneticus. As in cysts, a modification of the buccal-pharyngeal apparatus and claw reduction is also present in the winter stage of the life cycle of the marine species Halobiotus crispae (see Kristensen 1982). To withstand unfavorable conditions, the hibernal stage of $H$. crispae (stage "pseudosimplex 1"; Kristensen 1982) adopts a similar strategy to that used by cysts of $D$. parthenogeneticus and A. volubilis. As also hypothesized by Hansen \& Katholm (2002), the cuticular involucres should isolate the animal from the external environment (isolation also produced by the "closing" of mouth and cloaca openings) and to protect it from unfavorable environmental conditions. The relationships between reproduction and encystment found in A. nebulosus and represented by the production of summer and winter eggs (Hansen \& Katholm 2002) has not been found in A. volubilis. In A. nebulosus, Westh \& Kristensen (1992) and Hansen \& Katholm (2002) assert that during encystment a histolysis occurs, with the digestive system, stylets and claws that regress into embryonic cell bodies. The histolysis has been subject to many studies based on several species. These studies have led to discordant results. Authors such as Murray (1907), Richters (1909), Heinis (1910), and Westh \& Kristensen (1992) believe in a partial regression of internal organs, whereas Marcus (1929) and Węglarska (1957) believe, as we do, that the histolysis hypothesis is not correct. The supposed histolysis found in several species could be due to the difficulty of observing the internal organs in encysted animals because they are always very opaque within their cyst involucres.

Resting eggs are known for several animal groups. They are frequent in small crustaceans, such as anostracans, copepods, cladocerans, ostracods and in rotifers (Hairston \& De Stasio 1988; De Stasio 1989; Marcus et al. 1994; Brendonck 1996; Hairston et al. 1996; Rossi et al. 1996; Mura \& Zarattini 1999). In tardigrades, resting eggs have never been demonstrated, even though sometimes hypothesized due mainly to the presence of the uncommon phenomenon of two types of eggs in the 
same species (Pennak 1953; Baumann 1966; Westh \& Kristensen 1992; Kinchin 1994; Hansen \& Katholm 2002). In $M$. richtersi subitaneous and resting eggs are certainly present, but without morphological differences between them. These resting eggs need a cue to hatch (dehydration followed by rehydration), suggesting that another form of diapause may be possible in tardigrades. They should be studied more in depth but in any case they represent a further strategy to colonise and inhabit unpredictable environments.

\section{CONCLUSIONS}

Our studies on dormancy represent some of the first attempts to put life histories of cryptobiotic tardigrades into an ecological and evolutionary context. Tardigrades are a valid model organism for studies on dormancy, and studies on this group may provide valuable knowledge on dormant biological states to some applied sciences in a not to distant future. Although they are not able to survive a century in an anhydrobiotic state, as sometimes reported in texts and scientific magazines, a recovery after at least four years of anhydrobiosis in conditions similar to nature is in line with data from literature and should be considered a high long-term survival. It is rare that in nature and at our latitudes a lichen may stay dry for 2000 consecutive days. Even though the ability of these anhydrobiotic organisms to survive much longer than needed under natural conditions could seem not of great importance from an ecological point of view, we do not know its evolutionary perspectives. Nevertheless, the biochemical and physiological mechanisms that allow such long-term viability of dry cells are of obvious interest for more applied life sciences, such as medicine (Crowe \& Crowe 2000). The possibility to enter cryobiosis allows the existence of tardigrades in extreme environments such as polar areas or high mountains, where the animals spend a large part of the year in a frozen state. Cryptobiotic survival represents a successful strategy in environments with periods of hostile conditions. Apart from a protection against desiccation and freezing under natural conditions, cryptobiosis is also associated with a resistance against more unnatural abiotic extremes (Rahm 1921; Becquerel 1950; May et al. 1964; Seki \& Toyoshima 1998; Ramløv \& Westh 2001). As with unnatural long-term cryptobiotic survival, these resistances should not be considered adaptations but have probably arisen as byproducts of selection (Jönsson 2003). There are still few studies on intra- and interspecific differences in survival. Therefore, information on the microevolutionary aspects of dormancy, and the extent to which species living under different environmental conditions have diverged in dormancy patterns, is still scarce. Very little is also known about the energetic expense needed in the encystment process and on its molecular aspects.

The dormant forms in tardigrades (cyst, tuns, resting eggs) can be present at any stage of their life and repre- sent a genetic bank as they survive throughout extreme and ephemeral environment, preserving species diversity and provide a colonisation source when environmental conditions improve. In fact, they can give rise to a new population (parthenogenesis is frequent in nonmarine ecosystems, as well as self-fertilization) when the environmental condition are favourable, either in the same place already occupied, or in other habitats if passively dispersed.

\section{ACKNOWLEDGMENTS}

Financial support for these research projects and for attending the international workshop on "Diapause in Aquatic Invertebrates" in Pallanza (Italy) came from the "Italian Space Agency (ASI)" grant to L.R. Particular thanks to Clark W. Beasley, Department of Biology, McMurry University, Abilene (Texas, U.S.A.) for English revision of the manuscript.

\section{REFERENCES}

Altiero, T., L. Rebecchi \& R. Bertolani. (2004). Phenotipic variations in the life history of two clones of Macrobiotus richtersi (Eutardigrada, Macrobiotidae). Hydrobiologia: (in press).

Aroian, R.V., L. Carta, I. Kaloshian \& P.W. Sternberg. 1993. A free-living Panagroilamus sp. from Armenia can survive in anhydrobiosis for 8.7 years. J. Nematology, 25: 500-502.

Baumann, H. 1922. Die Anabiose der Tardigraden. Zool. Anz., 45: 501-556.

Baumann, H. 1966. Lebenslauf und Lebensweise von Hypsibius (H.) oberhaeuseri Doyère (Tardigrada). Veröff. Überseemus. Bremen, 5: 245-258.

Becquerel, P. 1950. La suspension de la vie au dessous de $1 / 20 \mathrm{~K}$ absolu par demagnetisation adiabatique de l'alun de fer dans le vide les plus elève. Compt. Rend. Seances Acad. Sci., Paris, 231: 261-263.

Brendonck, L. 1996. Diapause, quiescence, hatching requirements: what we can learn from large freshwater branchiopods (Crustacea: Branchiopoda: Anostraca, Notostraca, Conchostraca). Hydrobiologia, 320: 85-97.

Clegg, J.S. 1967. Metabolic studies of cryptobiosis in encysted embryos of Artemia salina. Comp. Biochem. Physiol., 20: 801-809.

Clegg, J.S. 2001. Cryptobiosis - a peculiar state of biological organization. Comp. Biochem. Physiol., 128: 613-624.

Cooper, A.F. \& S.D. Jr. Van Gundy. 1971. Senescence, Quiescence, and Anhydrobiosis. In: B.M. Zuckerman, W.F. Mai, R.A. Rohde (Eds), Plant Parasitic Nematodes. Cytogenetics, Host-Parasite Interactions, and Physiology. Academic Press, New York, 2: 297-318.

Crowe, J.H. 1975. The physiology of cryptobiosis in tardigrades. Mem. Ist. ital. Idrobiol., 32 Suppl.: 37-59.

Crowe, J.H. \& L. Crowe. 2000. Preservation of mammalian cells: learning nature's tricks. Nature Biotechnol., 18: 145146.

Demeure, Y., G. Reversat, S.D. Van Gundy \& D.W. Freckman. 1978. The relationship between nematode reserves and their survival to desiccation. Nematropica, 8: 7-8.

De Stasio, B.T. 1989. The seed bank of a freshwater crustacean: copepodology for the plant ecologist. Ecology, 70: $1377-1389$.

Doyère, P.L.N. 1842. Memoires sur le tardigrade. Sur le facilité possedent les tardigrades, les rotifers, les anguilleles des toit et quelques autres animacules, de 
renvenir à la vie après été complement déssechées. Ann. Sci. Nat., 18: 5.

Fielding, M.J. 1951. Observations on the length of dormancy in certain plant infecting nematodes. Proc. Helminthol. Soc. Washington D.C., 18: 110-112.

Guidetti, R., D. Boschini, L. Rebecchi \& R. Bertolani. (2004). Encystment processes and the "Matrioshka-like stage" in a moss-dwelling and in a limnic species of eutardigrades (Tardigrada). Hydrobiologia: (in press).

Guidetti, R. \& K.I. Jönsson. 2002. Long-term anhydrobiotic survival in semi-terrestrial micrometazoans. J. Zool., London, 257: 181-187.

Hairston, N.G. \& B.T. De Stasio. 1988. Rate of evolution slowed by dormant propagule pool. Nature, 336: 239-242.

Hairston, N.G. Jr., C.M. Kearns \& S. Ellner. 1996. Phenotypic variation in a zooplankton egg bank. Ecology, 77: 23822393.

Hand, S.C. 1991. Metabolic dormancy in invertebrates. $A d v$. Comp. Environm. Physiol., 8: 1-50.

Hansen, J.G. \& A.K. Katholm. 2002. A study of the genus Amphibolus from Disko Island with special attention on the life cycle of Amphibolus nebulosus (Eutardigrada: Eohypsibiidae). In: J.G. Hansen (Ed.), Arctic Biology Field Course Quqertarsuaq, 2002. Zoological Museum, University of Copenhagen, H.C.Ø. TRYK, Copenhagen, 129-163.

Heinis, F. 1910. Systematik und Biologie der Moosebewohnenden Rhizopoden, Rotatorien und Tardigraden usw. Archiv. Hydrobiologie Planktonkund., 5: 1-115.

Hickman, C.P. Jr., L.S. Roberts \& A. Larson. 1993. Integrated Principles of Zoology. IX ed. Mosby-Year Book, Inc., St. Louis.

Jönsson, K.I. 2003. Causes and consequences of excess resistance in cryptobiotic organisms. Physiol. Biochem. Zool., 76: 429-435.

Jönsson, K.I. \& R. Bertolani. 2001. Facts and fiction about long-term survival in tardigrades. J. Zool., London, 255: 121-123.

Jönsson, K.I. \& L. Rebecchi. 2002. Experimentally induced anhydrobiosis in the tardigrade Richtersius coronifer: phenotypic factors affecting survival. J. Exp. Zool., 293: 578584 .

Jönsson, K.I., S. Borsari \& L. Rebecchi. 2001. Anhydrobiotic survival in populations of the tardigrades Richtersius coronifer and Ramazzottius oberhaeuseri from Italy and Sweden. Zool. Anz., 240: 419-423.

Keilin, D. 1959. The problem of anabiosis or latent life: history and current concept. Proc. R. Soc. Lond. B., 150: 149191.

Kinchin, I.M. 1994. The Biology of Tardigrades. Portland Press, London: $145 \mathrm{pp}$

Kristensen, R.M. 1982. The first record of cyclomorphosis in Tardigrada based on a new genus and species from Arctic meiobenthos. Z. Zool. Systematik Evolut-forsh., 20: 249270.

Lee, D.L. 1961. Two new species of cryptobiotic (anabiotic) freshwater nematodes, Actinolaimus hintoni sp. nov. and Dorylaimus keilini sp. nov. (Dorylaimidae). Parasitology, 51: $237-240$.

Madin, K.A.C. \& J.H. Crowe. 1975. Anhydrobiosis in nematodes: carbohydrate and lipid metabolism during dehydration. J. Exp. Zool., 193: 335-342.

Marcus, E. 1929. Tardigrada. In: H.G. Bronn (Ed.), Klassen und Ordnungen des Tierreichs. Section 4, part 3, 5. Akademische Verlagsgesellschaft: 1-608.

Marcus, N.H., R. Lutz, W. Burnett \& P. Cable. 1994. Age, variability, and vertical distribution of zooplancton resting eggs from an anoxic basin: evidence of an egg bank. Limnol. Oceanogr., 39: 154-158.

May, R.M., M. Maria \& J. Guimard. 1964. Actions différentielles des rayons x et ultraviolets sur le tardigrade Macro- biotus areolatus, à l'état actif et desséché. Bull. Biol. France Belgique, 98: 349-367.

McGlohon, N.E., J.N. Sasser \& R.T. Sherwood. 1961. Investigation on plant-parasitic nematodes associated with forage crops in North Carolina. Technical bulletin 148, North Carolina Agricultural Experimental Station, North Carolina State College, Raleigh.

Menti, H., D.J. Wright, \& R.N. Perry. 1997. Desiccation survival of populations of the entomopathogenic nematodes Steinernema feltiae and Heterorhabditis megidis from Greece and the UK. J. Helminthol., 71: 41-46.

Mura, G. \& P. Zarattini. 1999. Influence of parental rearing conditions on cyst production and hatching of Chirocephalus ruffoi, an endemic fairy shrimp from Italy (Anostraca). Crustaceana, 72: 449-465.

Murray, J. 1907. The encystment of Macrobiotus. Zoologist, 11: 4-11.

Örstan, A. 1998. Factors affecting long-term survival of dry bdelloid rotifers: a preliminary study. Hydrobiologia, 387/388: 327-331.

Pennak, R.W. 1953. Fresh-water invertebrates of the United States. Ronald Press, New York: 769 pp.

Pigòn A., Wegglarska B. 1953. The respiration of Tardigrada: a study in animal anabiosis. Bull. Acad. Pol. Sci., 1: 69-72.

Rahm, P.G. 1921. Biologische und physiologische Beiträge zur Kenntnis der Moosfauna. Zeitschr. allg. Physiol., 20: $1-34$.

Ramazzotti, G. 1962. Il phylum Tardigrada. Mem. Ist. ital. Idrobiol., 14: 1-595.

Ramløv, H. \& P. Westh, P. 1992. Survival of the cryptobiotic eutardigrade Adorybiotus coronifer during cooling to -196 ${ }^{\circ} \mathrm{C}$ : effect of cooling rate, trehalose level, and short-term acclimation. Cryobiology, 29: 125-130.

Ramløv, H. \& P. Westh. 2001. Cryptobiosis in the eutardigrade Adorybiotus (Richtersius) coronifer: tolerance to alcohols, temperature and de novo protein synthesis. Zool. Anz., 240: 517-523.

Rebecchi, L., R. Guidetti, S. Borsari, T. Altiero \& R. Bertolani. (2004). Dynamics of long-term anhydrobiotic survival of lichen-dwelling tardigrades. Hydrobiologia: (in press).

Ricci, C. 1998. Anhydrobiotic capability of bdelloid rotifers. Hydrobiologia, 387/388: 321-326.

Richters, F. 1909. Tardigraden-Studien. Ber. Senckenbergischen Naturfrorsch. Gesellschaft Frankfurt: 28-45.

Rossi, V., A. Gandolfi \& P. Menozzi. 1996. Egg diapause and clonal structure in parthenogenetic populations of Heterocypris incongruens (Ostracoda). Hydrobiologia, 320: 4554 .

Seki, K. \& M. Toyoshima. 1998. Preserving tardigrades under pressure. Nature, 395: 853-854.

Shen, M.J., M.B. Mudgett, J.W. Schorf, S. Clarke \& R. Berger. 1995. Exceptional seed longevity and robust growth: ancient sacred lotus from China. Am. J. Botany, 82: 13671380.

Steiner, G. \& F.E. Albin. 1946. Resuscitation of the nematode Tylenchus polyhypnus $\mathrm{n}$. sp. after almost 39 years' dormancy. J. Washington Acad. Sci., 36: 97-99.

Townshend, J.L. 1964. Anhydrobiosis in Pratylenchus penetrans. J. Nematology, 16: 282-289.

Vreeland, R.H. 2000. Isolation of a 250 million-year-old bacterium from a primary salt crystal. Nature, 407: 897-900.

Westh, P. \& R.M. Kristensen 1992. Ice formation in the freeze-tolerant eutardigrades Adorybiotus coronifer and Amphibolos nebulosus studied by differential scanning calorimetry. Polar Biol., 12: 693-699.

Westh, P. \& H. Ramløv 1991. Trehalose accumulation in the tardigrade Adorybiotus coronifer during anhydrobiosis. $J$. Exp. Zool., 258: 303-311.

Weqglarska, B. 1957. On the encystation in Tardigrada. Zool. Pol., 8: 315-325. 
Womersley, C. 1981. Biochemical and physiological aspects of anhydrobiosis. Comp. Biochem. Physiol., 70: 669-678.

Wright, J.C. 1989. Desiccation tolerance and water-retentive mechanisms in tardigrades. J. Exp. Biol., 142: 267-292.
Wright, J.C. 2001. Cryptobiosis 300 years on from van Leuwenhoek: what have we learned about tardigrades? Zool. Anz., 240: 563-582. 